\title{
Making and Unmaking Roman Landscapes in Cicero and Caesar
}

\author{
Isabel K. Köster
}

Landscapes become Roman in a process of transformation. ${ }^{1}$ They are divided up and acquire new markers and features. ${ }^{2}$ Urban settlements expand or shrink as necessary in order to meet the needs of the population. The lifestyle of the people living on the land also changes as Roman and local identities fuse into hybrid cultures. The visibility of these processes in the archaeological record is explored in other papers in this volume. This contribution, by contrast, focuses on literary texts and the question of how foreign landscapes are transformed into Roman ones. More specifically, it explores what Cicero and Caesar tell us about the characteristics of a Roman (or potentially Roman) landscape and how it can be differentiated from other spaces.

For Cicero and Caesar, I argue, the physical features of a landscape are indicative of its ideal function. Humans can either use the landscape in a way that matches its purpose or they can violently intervene in order to put it to a different use. ${ }^{3}$ As Diana Spencer has argued, a landscape is created by the

1 I am grateful to the organizers and participants of Impact of Empire 14 for a stimulating workshop and to the editors of this volume for their feedback. The Latin texts follow the Oxford Classical Text editions for the Verrines and Caesar and L. Grillo, Cicero's De Provinciis Consularibus Oratio (Oxford 2015). Translations are my own.

2 The bibliography on how the Romans transform foreign landscapes is extensive. A few examples will suffice: C. Nicolet, Space, Geography, and Politics in the Early Roman Empire (Ann Arbor 1991); G. Woolf, Becoming Roman: The Origins of Provincial Civilization in Gaul (Cambridge 1998); F. Carlà-Uhink, The "Birth" of Italy as a Region, 3rd-1st Century BCE (Berlin 2017); C. Roncaglia, Northern Italy in the Roman World: From the Bronze Age to Late Antiquity (Baltimore 2018).

3 For Cicero, E. Römisch, 'Umwelt und Atmosphäre. Gedanken zur Lektüre von Ciceros Reden', in G. Radke (ed.), Cicero. Ein Mensch seiner Zeit (Berlin 1968), 117-135 and A. Vasaly, Representations: Images of the World in Ciceronian Oratory (Berkeley 1993) offer pioneering studies of how landscape descriptions function as persuasive tools. Since the publication of these studies, there has been considerably more work on landscapes in Latin literature. A significant body of scholarship focuses on the interplay between foreign landscapes and notions of ethnicity (see also Vasaly 1993 op. cit. [n. 3], 131-155; 191-244), with the general idea that a landscape and the people it produces share characteristics (the Roman work on the topic owes a debt to F. Hartog, The Mirror of Herodotus: The Representation of the Other in the 
interplay between humans and space: the term " $[1]$ andscape' ... foregrounds the cultural context and emphasizes the relationship between humankind, nature, and the inhabited world." ${ }^{4}$ A landscape, then, is a space with an identity and a purpose that is accorded to it by humans. Ideally, a landscape's perceived purpose and its human use are in harmony. When they are not, the most extreme consequence is the creation of an "anti-landscape," a term coined by the environmental historian David Nye in order to describe landscapes that, often as a result of human actions, cannot be inhabited. ${ }^{5}$ In this chapter, I use Nye's concept of anti-landscapes as a lens on Cicero's and Caesar's descriptions of Gaul. After setting anti-landscapes in dialog with more traditional notions of landscapes in Roman texts, I turn to Cicero's On the Consular Provinces and Caesar's Gallic War in order to explore whether these two texts treat Gaul as a space that has the potential to become a Roman landscape.

\section{Landscapes and Anti-landscapes}

In order to explore anti-landscapes, it is useful to first look at a case where a landscape's identity and its use by humans are not in conflict. An illustrative example comes from in Cicero's Verrines. Gaius Verres, the defendant, according to Cicero, is entirely unfamiliar with Roman cultural norms. ${ }^{6}$ He has consistent difficulties grasping the intended purpose of objects and spaces and does not know how to behave in a particular environment. As a result, Verres' actions regularly lead to destruction and suffering. The sanctuary of Ceres at Henna in central Sicily offers an example of what happens when Verres misunderstands the purpose of a space. He should have easily recognized it as a sanctuary within a wider sacred landscape (Cic. Verr. 2.4.106-107):

It is a long-held view, judges, which is affirmed by the oldest Greek works of literature and by monuments, that the island of Sicily as a whole is consecrated to Ceres and Libera. [...]. Henna [...] is built on a very high

Writing of History (Berkeley 1988), esp. 112-141, which pioneered these notions for the study of Herodotus). As I aim to show in this chapter, the idea of a correspondence between people and landscape can also be unstable.

4 D. Spencer, Roman Landscape: Culture and Identity (Cambridge 2010), 1.

5 D.E. Nye, 'The anti-landscape,' in D.E. Nye and S. Elkind (eds.), The Anti-Landscape (Amsterdam 2014), 11-26.

6 See, e.g., S. Koster, Die Invektive in der griechischen und römischen Literatur (Meisenheim am Glan 1980), 113-115; J.M. May, Trials of Character: The Eloquence of Ciceronian Ethos (Chapel Hill 1988), 31-47. 
spot, the top of which is flat and always has water; all approaches are sheer and steep. Around it are many lakes and groves and copious flowers at all times of year so that it seems to identify itself as the very place from which the maiden [Libera] was snatched, which we have already learned about [accepimus] since childhood. Indeed, there is a certain cave nearby, open to the north, incredibly deep, from which they say Father Dis suddenly emerged with his chariot, took the maiden from that place and carried her off with him. And quickly, not far from Syracuse, he plunged under the earth, and a lake suddenly appeared in that place, where until today the Syracusans hold an annual feast day with throngs of men and women. ${ }^{7}$

The description of the landscape is central to Cicero's rhetorical strategy. It authenticates the sacred importance of the location: a visitor to the site (or, with some imagination, someone reading or listening to the speech) can see the cave from which the god of the underworld emerged, can verify that this is a location where Persephone could have been picking flowers and so on. Therefore, although Cicero started by affirming that the site is sacred because of its place in Greek mythology, the description of the landscape introduces a further element: it is a space that Romans also know about from childhood stories. ${ }^{8}$ With the shift to the first-person plural verb accepimus in the middle of the passage, Henna becomes the common property of Greeks and Romans and Verres has attacked a universally sacred space: for those who know their mythology, the physical features of Sicily's landscape authenticate the island's connection to the gods. The festivals underscore the sacred function of the landscape and oral tradition - the tales that all somewhat educated Romans have been told since childhood - further confirms it. Henna, in Cicero's

7 Vetus est haec opinio, iudices, quae constat ex antiquissimis Graecorum litteris ac monumentis, insulam Siciliam totam esse Cereri et Liberae consecratam. [...]. Henna [...] est loco perexcelso atque edito, quo in summo est aequata agri planities et aquae perennes, tota vero ab omni aditu circumcisa atque directa est; quam circa lacus lucique sunt plurimi atque laetissimi flores omni tempore anni, locus ut ipse raptum illum virginis quem iam a pueris accepimus declarare videatur. etenim prope est spelunca quaedam conversa ad aquilonem, infinita altitudine, qua Ditem patrem ferunt repente cum curru exstitisse, abreptamque ex eo loco virginem secum asportasse, et subito non longe a Syracusis penetrasse sub terras, lacumque in eo loco repente exstitisse, ubi usque ad hoc tempus Syracusani festos dies anniversarios agunt celeberrimo virorum mulierumque conventu.

8 This is not the only instance in which Cicero blames Verres' lack of education for his crimes. At Cic. Verr. 2.1.47-48 the orator mocks the defendant for not having learned that Delos is a sacred island. 
rhetoric, is a landscape naturally suited to being sacred to the Romans and has always been so.

Passages such as this raise a number of questions about landscapes in Roman rhetoric and historiography: Sicily, after all, was conquered by the Romans, so how can it have a landscape that was always ideally suited to its Roman use? Land is conquered, but does Roman military action and imperial ambition also change how a space is written about? What features does a Roman landscape need to have to be recognizable as Roman and how do those qualities differ from those of a non-Roman space? Cicero's vision of Henna as an ideal Roman sanctuary also asks us to contemplate the relationship between humans and landscapes. In the passage above, human action enhances the function of the landscape. It is equally possible, however, especially in the context of military conquest, to imagine humans and landscapes working against each other: land can be suited for use by the Romans, but its inhabitants may resist conquest. By the same token, a landscape may resist those that try to inhabit it.

The concept of an anti-landscape offers a framework for exploring the complex interplay between landscapes and their inhabitants. As David Nye defines the concept, "[a]nti-landscapes are spaces that do not sustain life. They may arise from natural causes but are often the consequence of human action." ${ }^{9}$ Anti-landscapes have all the regular features of a landscape (such as roads, houses, and elements of topography), but are uninhabitable either because of a natural disaster or because of some destructive human action. They can have clearly defined geographical boundaries or they can be amorphous or even spread to adjacent spaces. For Nye, an important characteristic of antilandscapes is what he calls their 'narrative': an inhabitable landscape is rendered hostile and useless, but can, with time and effort, be recovered for human use. ${ }^{10}$ Central to the notion of an anti-landscape, then, is the importance of an outside influence and the impermanence of the space's hostility to human life.

Nye's anti-landscapes are useful because they shift the focus to developments and transitions and thematize the hostility of a space. They ask us to contemplate what the opposite of a landscape would look like. In order to use the concept to explore Cicero and Caesar, however, two adaptations are necessary. First, the anti-landscapes are to be understood as hostile only to Roman life. Secondly, narratives of transformation are rare in these two accounts: except for occasions where Caesar destroys a landscape in the course of a

$9 \quad$ Nye 2014, op. cit. (n. 5), 11.

10 Nye 2014, op. cit. (n. 5), especially 20-25; D.E. Nye, 'Superfund sites as anti-landscapes', in S. Hartman (ed.), Contesting Environmental Imaginaries: Nature and Counternature in a Time of Global Change (Leiden 2017), 283-305. 
campaign, landscapes are either hostile or they are not. Human agency can either enhance the inherent hostility of the landscape (and hence create a Roman anti-landscape) or create a conflict with a landscape that is willing to become Roman. Unlike in Nye's model, therefore, the landscapes have their own characteristic preferences and are not merely the passive recipients of outside forces. ${ }^{11}$

\section{Cicero on Gaul}

When we turn to Cicero and Caesar, we are faced with the question of whether Gaul is an anti-landscape without potential to transform into a productive part of the Roman world or whether it is only the human population that tries to resist the Romans. Cicero's response suggests that although it is possible to conquer Gaul militarily, it is at best uncertain whether it will ever be a productive part of Rome. This ambiguity is an important element of On the Consular Provinces. Cicero delivered the speech in favor of extending Caesar's extraordinary command in Gaul in 56 вСЕ, a couple of years into the campaigns. His fellow senators, according to Cicero, are faced with a choice: they can either allow Caesar to consolidate the conquest of the territory or they can assign the province to someone else and have it slip from their grasp. Neither the landscape nor the people in Gaul are naturally suited to being Roman: there is no possibility of holding on to the new territories without the use of force.

If Rome loses control, this would undo a long series of Roman achievements. According to Cicero, the world has already effectively been conquered. ${ }^{12}$ As he puts it: "There are no people who have not either been so destroyed that they just barely continue to exist, or so subdued that they keep quiet, or so disposed towards peace that they are happy about our victory and dominion."13 These, then, are the three approaches for dealing with the inhabitants of

11 My thoughts regarding the agency of ancient landscapes owe a debt to L. Van Broeck, 'Wily wetlands: imperialism and resistance in Tacitus's Batavian revolt', in D. Felton (ed.), Landscapes of Dread in Classical Antiquity: Negative Emotion in Natural and Constructed Spaces (London 2018), 145-162.

12 For the vision of world domination that Cicero articulates in the speech, see A.M. Riggsby, Caesar in Gaul and Rome: War in Words (Austin 2006), 21-24.

13 Nulla gens est, quae non aut ita sublata sit, ut vix exstet, aut ita domita, ut quiescat, aut ita pacata, ut victoria nostra imperioque laetetur (Cic. prov. 31). I follow M. Lavan, 'Peace and empire: Pacare, pacatus and the language of Roman imperialism', in E.P. Moloney and M.S. Williams (eds.), Peace and Reconciliation in the Classical World (London 2017), 102-114, in translating pacata in a way that does not suggest violent Roman pacification, but rather a more cooperative process. 
conquered territories: near-annihilation, active suppression, and persuasion. Caesar employs all three strategies and knows exactly what is required in every situation. ${ }^{14}$

Gaul is a military problem, not an administrative one. This point becomes especially clear in the comparison between Caesar's assignment and the tasks given to L. Calpurnius Piso and Aulus Gabinius, the governors of Macedonia and Syria respectively. An extension of Caesar's extraordinary command in Gaul would generate a shortage of provinces to assign to the next set of consuls. As a solution, Cicero proposes that Piso and Gabinius should be recalled. They, according to the orator, were assigned two provinces that were ideally suited to Roman rule, but proved so incompetent that they have pushed those territories to the brink of unrest. By linking the political fates of Caesar, Piso, and Gabinius, the speech therefore provides an insight into what Cicero considers to be the characteristics of an ideal Roman province.

Whereas Gaul is still the site of active conflict, Macedonia and Syria used to be peaceful provinces that are now being destabilized by their governors. Cicero's short description of the situation in Macedonia is illustrative (Cic. prov. 5):

And we used to keep this [province of] Macedonia secure, once it was quiet and peaceful of its own accord [per se], after the neighboring people had been subdued and the foreign threat had been contained, with a small garrison and a meagre number of soldiers even without imperium, through legates, by the name of the Roman people itself. ${ }^{15}$

There is a sharp contrast between Macedonia itself and neighboring regions. Whereas those living around the province have to be conquered, very little military force is needed to deal with Macedonia. It is willingly and naturally (per se) peaceful. Furthermore, the boundaries of the province are clear: Macedonia is not a place where Romans have to engage in military action because that would go against the nature of the province. ${ }^{16}$ When governed competently, Macedonia is a stable and peaceful province that covers a clearly defined territory.

\footnotetext{
14 Cic. prov. 33 .

15 Atque hanc Macedoniam domitis iam gentibus finitimis barbariaque compressa pacatam ipsam per se et quietam tenui praesidio atque exigua manu etiam sine imperio per legatos nomine ipso populi Romani tuebamur.

16 Cicero's vision of Macedonia is a fantasy since the province saw regular military conflicts. For an overview of the strategic situation, see See Grillo 2015, op. cit. (n. 1), ad 5.10 and 5.12.
} 
Rome's enemies, by contrast, have no respect for provincial spatial demarcations. Looking back at the Mithridatic Wars, Cicero pictures the king's forces as "boiling over and erupting into Asia."17 The motif that the inhabitants of Roman provinces stay quietly within their territories, whereas enemies constantly look to transgress their boundaries runs throughout the speech. ${ }^{18}$ It is particularly prominent with the Gauls. They, in Cicero's argument, have no sense of borders. Caesar is the only one who can stop regular incursions into Italy (Cic. prov. 32):

A Gallic War, Senators, has been conducted under the general C. Caesar. Before this we only repelled the Gauls. The distinguished C. Marius, whose divine and outstanding courage brought relief to the great calamities and disasters of the Roman people, stopped the enormous hordes of Gauls streaming into Italy, but did not himself press into their cities and dwellings. ${ }^{19}$

The language of the passage is vivid with the Romans trying to stand their ground by repelling invaders who simply flow over them. The Gauls disrupt and destabilize the integrity of Roman space.

The growing unrest in Macedonia and Syria illustrates what happens when Roman territories are not properly protected. The lack of respect for boundaries can be contagious. Here we can return to the concept of the anti-landscape. Anti-landscapes, too, need not have fixed boundaries, but can spread and infect surrounding territory. ${ }^{20}$ Landscapes that border on anti-landscapes, then, can potentially be rendered unfit for human use just by nature of their geographical location. By being fluid and ill-defined and threatening to take over Roman territory, the spaces bordering Macedonia and Syria and the entirety of Gaul are, in effect, Roman anti-landscapes.

To be sure, the fluidity of Rome's foreign neighbors is primarily a problem of people and not territory. The physical space, however, also poses a threat

17 Effervescentem in Asiam atque erumpentem (Cic. prov. 6).

18 On this point see also Grillo 2015, op. cit. (n. 1) ad 5.10: "Throughout Prov. barbarians constitute a potentially overflowing danger that must be subdued." Riggsby examines the speech from an 'insider/outsider' model where "a peaceful interior [is] rigidly distinguished from a dangerous exterior," Riggsby 2006, op. cit. (n. 12), 21-24, quotation from 21. Roman and non-Roman spaces are fundamentally different.

19 Bellum Gallicum, patres conscripti, C. Caesare imperatore gestum est, antea tantum modo repulsum ... ipse ille C. Marius, cuius divina atque eximia virtus magnis populi Romani luctibus funeribusque subvenit, influentes in Italiam Gallorum maximas copias repressit, non ipse ad eorum urbes sedesque penetravit.

Nye 2014, op. cit. (n. 5), 19-20. 
because it does not conform to Roman patterns of habitation. Although the Gauls also have urban settlements, these, in contrast to Macedonia and Syria, do not show any evidence of cultural or artistic activities (Cic. prov. 29):21

For why is it that Caesar himself wishes to stay in his province unless it is to hand over to the state as accomplished the things that he has aimed for? I suppose that the pleasantness of the place, the beauty of its cities, the culture and refinement of those people and their tribes, the desire for victory, and the extension of the boundaries of the empire keep him there. What is more hostile than those lands, what more uncultured than those towns, what more wild than those tribes, what, moreover, more distinguished than those victories? What can be found to be further away from the Ocean? ${ }^{22}$

With this negative characterization of Gaul, Cicero attempts to address concerns that Caesar may not give up the territories he conquered at the end of the campaign. There is nothing attractive or desirable about the territory: the threat to Roman space must be dealt with, nothing more. And it is not just human life that presents a problem: the land itself is hostile and the cities are not centers of refinement, but symbols of its absence. Then there is the reference to the Ocean and the idea that Caesar's campaigns extend to the edge of the world. It is a common trope in Greek and Latin literature that the further away one goes from the known world, the stranger things get: one can reach paradisiacal landscapes or strange lands where markers of space have ceased to have their regular meaning. ${ }^{23}$ The latter is the case with Cicero's Gaul - the landscape has no features except for cities that are not really cities. It follows that the territory can perhaps be subdued, but that it cannot be transformed into a peaceful province like Macedonia.

The Alps are the most notable topographical feature of Gaul in Cicero's speech, but the Gauls are constantly in danger of transgressing them. Once

21 As shown in E. Ndiaye, 'L'image du barbarus gaulois chez Cicéron et César,' Vita Latina 177 (2007), 87-99, the idea that the Gauls are entirely lacking in culture is a trope in Cicero's works, especially in his speeches.

22 Nam ipse Caesar quid est cur in provincia commorari velit, nisi ut ea, quae per eum adfecta sunt, perfecta rei publicae tradat? amoenitas eum, credo, locorum, urbium pulchritudo, hominum nationumque illarum humanitas et lepos, victoriae cupiditas, finium imperii propagatio retinet. quid illis terris asperius, quid incultius oppidis, quid nationibus immanius, quid porro tot victoriis praestabilius, quid Oceano longius inveniri potest?

23 On this literary trope, see J.S. Romm, The Edges of the Earth in Ancient Thought (Princeton 1992), esp. 20-26; A. Purves, 'Unmarked space: Odysseus and the inland journey,' Arethusa 39 (2006), 1-20. 
Caesar has conquered the territory, there is no longer a need for the mountain range. As Cicero tells his audience: "Let the Alps sink. For there is nothing beyond the peak of those mountains up to the ocean that Italy must fear."24 After all, Gaul, in the orator's conception, is not a clearly defined geographical space, but simply the area where Gauls come from. Once they have been crushed, everything is in order. It follows that Gaul is not a territory with the potential to become part of the Roman world: it is either the home of invaders or it is nothing.

Cicero's Gaul is an anti-landscape inhabited by people who do not respect Roman boundaries. With its lack of clear features or recognizable patterns of urban settlements, the physical space mirrors the mobility of the population: like some anti-landscapes, it threatens to take over and destabilize surrounding territories. Without Caesar's intervention, the territory is not only unsuitable for Roman habitation, but a constant danger to Roman space. Cicero's speech therefore reflects the threatening potential of anti-landscapes.

\section{3}

\section{Caesar on Gaul and Germany}

Julius Caesar himself has a different outlook on the issue of whether Gaul can become Roman. As scholarship on Caesar's account of the Gallic War has shown extensively, when it comes to the general's description of Gaul, he looks at the territory thinking about how it can be divided up and turned into Roman land. ${ }^{25}$ Unlike Cicero, he carefully differentiates between the territory (which is suitable for Roman habitation) and the people (who are largely uncooperative and unwilling to stay within their naturally given boundaries). There is nothing uncivilized about Caesar's Gaul: it is densely settled with tribes that can be neatly separated from each other. The land is fertile and suitable for sustaining large settlements: when it is not, then it is often because of destruction caused by humans. Therefore, although Caesar and Cicero refer to the same physical territory when they talk about Gaul, the two authors have fundamentally different conceptions about the nature of the space.

\footnotetext{
24 Quae [=Alpes] iam licet considant. nihil est enim ultra illam altitudinem montium usque ad Oceanum, quod sit Italiae pertimescendum (Cic. prov. 34).

25 M. Rambaud, 'L'espace dans le récit césarien', in R. Chevallier (ed.), Littérature grécoromaine et géographie historique: mélanges offerts à Roger Dion (Paris 1974), 111-129; Riggsby 2006, op. cit. (n. 12), esp. 24-45; C.B. Krebs, 'The world's measure: Caesar's geographies of Gallia and Britannia in their contexts and as evidence for his world map' AJPh 139 (2018), 93-122.
} 
At the beginning of Book 1 of the Gallic War, Caesar finds himself in conflict with the Helvetii. A prominent leader named Orgetorix compelled this tribe to cross its boundaries even though such a move went against the very nature of the territory (Caes. Gall. 1.2.3-4):

The Helvetii are contained on all sides by the nature of the place: on one side by the very broad and deep Rhine River, which divides the land of the Helvetii from the Germans; on another side [they are hemmed in] by the very high Jura Mountains, which are between the Sequanii and the Helvetti; on the third side by Lake Geneva and the Rhone, which separate our province from the Helvetii. Because of these circumstances, they do not roam very far. ${ }^{26}$

This is an orderly world in which every tribe has a designated space. The move on the part of the Helvetii is a violation of the natural order. ${ }^{27} \mathrm{~A}$ few chapters later, after Orgetorix is killed, the Helvetii decide to go on an all-out offensive (Caes. Gall. 1.5.2-4):

When they considered themselves to be ready for this endeavor, they set on fire all their towns, in number about twelve, about forty villages, and the remaining private buildings. They burned all their grain, except what they would carry with them, so that, because the hope of a return home had been taken away, they would be more ready to face any danger. They ordered each person to bring with them a supply of grain for three months. They persuaded the neighboring Rauraci, Tulingi, and Latobrigi to take the same advice and set out together with them once they had burned their towns and villages. ${ }^{28}$

26 Undique loci natura Helvetii continentur: una ex parte flumine Rheno latissimo atque altissimo, qui agrum Helvetium a Germanis dividit; altera ex parte monte Iura altissimo, qui est inter Sequanos et Helvetios; tertia lacu Lemanno et flumine Rhodano, qui provinciam nostram ab Helvetiis dividit. his rebus fiebat ut et minus late vagarentur.

27 As has been well-recognized, Caesar's efforts to give a such a neat and orderly picture of the physical landscape result in significant geographical distortions and inaccuracies, see G. Walser, 'Zu Caesars Tendenz in der geographischen Beschreibung Galliens,' Klio 77 (1995), 217-223; C.B. Krebs, '“Imaginary geography” in Caesar's Bellum Gallicum,' AJPh 127 (2006), 111-136. For distortions in Caesar's ethnographic narratives, see A. Johnston, 'Nostri and "the other(s)"', in L. Grillo and C.B. Krebs (eds.), The Cambridge Companion to the Writings of Julius Caesar (Cambridge 2017), 81-94. On Caesar's rhetorical distortions more broadly, M. Rambaud, L'art de la déformation historique dans les Commentaires de César (Paris 1953) is fundamental.

28 Ubi iam se ad eam rem paratos esse arbitrati sunt, oppida sua omnia, numero ad duodecim, vicos ad quadringentos, reliqua privata aedificia incendunt; frumentum omne, praeterquam 
In order to motivate themselves for the campaign, the Helvetii effectively destroy their civilization and inspire others to do the same. Once Caesar wins a decisive victory, his first order of business is to compel the defeated to undo as much of the damage as possible so that orderly life can resume. The only hostile element in passages such as this is Gaul's human population. They have to work against the physical landscape in order to fight the Romans.

In the case of the Helvetii, the landscape itself is not hostile. Elsewhere in the Gallic War, however, Caesar and his troops regularly find themselves confronted with swamps, woods or ravines that make operations difficult and give some advantage to the enemy's battle tactics. ${ }^{29}$ An extended example of this pattern is Caesar's confrontation with the Nervii (Gall. 2.16-28). While the Romans identify a suitable space to make camp, they quickly find themselves attacked by enemies hiding in the surrounding woodlands (Gall. 2.18-19). In his description of the ensuing battle, Caesar repeatedly points to the difficult nature of the territory, which prompts the Romans to adjust their tactics. ${ }^{30}$ In the end, the general's leadership and the skill of his soldiers win the day, but the episode illustrates a victory over both a fierce enemy and a territory that does not conform to Roman preferences. From a military point of view, the land of the Nervii is almost a Roman anti-landscape: it is hostile to them, but can be adapted to, if with difficulty.

The confrontation with the Menapi and Morini in Book 3 illustrates a different approach to potential anti-landscapes. ${ }^{31}$ The territory is covered with woods and swamps, which the inhabitant think will shield them from the Romans. This is, after all, a terrain that has proven to be hostile to the invaders: it is a Roman anti-landscape, but a useful space for the Gauls. In response, Caesar orders his men to chop down the woods, which they initially do easily and at a rapid pace. ${ }^{32}$ When a storm interrupts the operation, an even more radical approach is called for and the general orders much of the territory to be

quod secum portaturi erant, comburunt, ut domum reditionis spe sublata paratiores ad omnia pericula subeunda essent; trium mensum molita cibaria sibi quemque domo efferre iubent. persuadent Rauracis et Tulingis et Latobrigis finitimis suis, uti eodem usi consilio oppidis suis vicisque exustis una cum eis proficiscantur.

29 On these spaces and the dangers that they pose, see Riggsby 2006, op. cit. (n. 12), 25-27. As Riggsby points out, while these spaces slow down and threaten the Romans, they can still move in them and frequently also manage to successfully fight in them.

30 For example, "Since the army had taken up a formation that was dictated more by the nature of the territory, the slope of the hill, and what was necessary in the moment than it was by military tactics and order [...]." (Instructo exercitu magis ut loci natura deiectusque collis et necessitas temporis quam ut rei militaris ratio atque ordo postulabat, [...]. Caes. Gall. 2.22.1).

31 Caes. Gall. 3.28-29.

32 The trees are removed "with incredible speed" (incredibili celeritate, Caes. Gall. 3.29.2). 
set on fire. The decision to end the conflict through slashing and burning illustrates that Caesarian anti-landscapes are not hostile to all human life. When the area was friendly to the Gauls, it was unsuitable for Roman use. Through violent intervention, however, the land is transformed into a space hostile to the Gauls and can thereby be added to Caesar's conquests. It would of course take significant effort to restore the burnt landscape to human use, but such considerations are beyond the general's concerns. Creating an anti-landscape has helped advance the military objective.

Caesar's Gaul therefore presents three variations on the idea of antilandscapes: some territories are easily adapted to Roman occupation even though their inhabitants try to resist, others need to be overcome by military skill and ingenuity, yet others have to be destroyed and made unusable for their Gallic inhabitants in order to suit Roman plans. None of the spaces that Caesar encounters in Gaul therefore fully meet Nye's criteria for anti-landscapes: The Romans face difficulties, but the environment does not make their existence impossible.

Britain and Germany present a rather different picture. Caesar's campaigns take him there, too, but not with a view to staying. As most notably has been argued by Christopher Krebs, the lands of Britain and Germany are cast as entirely unsuitable for Roman conquest. ${ }^{33}$ It is therefore no surprise that not only the people, but also the landscape is hostile. In Britain the ships struggle to find a safe space to anchor, and frequent storms throw off Roman efforts. ${ }^{34}$ Furthermore, impenetrable forests cover the land. Although there are no cities, this space is reminiscent of Cicero's Gaul. ${ }^{35}$ It, too, presents a featureless landscape and offers the Romans nothing except resistance. Whereas Gaul has to be conquered for reasons of Roman security, it is enough to persuade the Britons to no longer foment unrest among different Gallic factions.

When we get to Caesar's Germany, it becomes even more obvious that there is little beyond the boundaries of Gaul that resembles civilization in Roman eyes. As discussed above, the Helvetii burned their settlements in order to motivate themselves to go to war. The destruction was an undesirable necessity. In Germany, however, wastelands are objects of prestige. One of the most

\footnotetext{
33 Krebs 2006, op. cit. (n. 27); Krebs 2018, op. cit. (n. 25).

34 See especially Caes. Gall. 4.28-29.

35 While it is likely that Caesar shaped Cicero's views of Gaul as a coherent geographical space (see, for example, Krebs 2006, op. cit. (n. 27), 115-116), the lack of repeated phrases and similar linguistic markers makes it difficult to determine whether Caesar specifically projected Cicero's view of the nature of Gaul onto his characterization of Britain and Germany. It is more probable that the two authors are simply employing the same broad views of what a complete absence of civilization looks like.
} 
remarkable features of the German tribes, according to Caesar, is that they like to surround themselves with uninhabitable spaces (Caes. Gall. 6.23.1-2): ${ }^{36}$

It is the greatest glory in these lands to surround oneself with the widest possible extent of empty spaces [solitudines] by laying waste to the borderlands. They consider this a characteristic of valor: to have their neighbors withdraw having been driven from their lands and to have no-one dare to settle nearby. ${ }^{37}$

The Latin word that Caesar uses to describe the space between tribes is solitudo, which signifies any sort of uninhabited and hostile space such as a desert. ${ }^{38}$ Whereas in Gaul people constantly transgress their boundaries, Caesar's Germans are keen on demarcating their territory. ${ }^{39}$ A land covered in woods where hostile emptiness is a desired boundary marker is indeed no space for Romans. Caesar, then, indicates clearly what territories he means to conquer and what territories he considers unsuitable for the Romans. Gaul's land is either portrayed as already friendly to the Romans or as territory that can be overcome by force or ingenuity. Fully hostile anti-landscapes lie beyond the borders of potentially Roman space.

\section{$4 \quad$ Conclusion}

Cicero and Caesar have different perspectives on Gaul's future as a Roman landscape. For the orator, who is arguing for the continuation of a war, there is little in Gaul that resembles Roman space. There are some settlements and topographical features such as rivers, but for the most part the landscape is ill-defined and difficult to contain. Humans and space work together to resist the Romans: people transgress boundaries such as the Alps and the supposedly imposing mountain range facilitates their moves. This is territory that the

36 See also Caes. Gall. 4.3, which also mentions that the German tribes surround themselves with empty space.

37 Civitatibus maxima laus est quam latissime circum se vastatis finibus solitudines habere. hoc proprium virtutis existimant, expulsos agris finitimos cedere, neque quemquam prope audere consistere....

38 Solitudo is also the term that Tacitus' Calgacus uses at Tac. Agr. 30 to describe what land looks like after it has been conquered by the Romans.

39 As also noted in Riggsby 2006, op. cit. (n. 12), 64-65, there is a significant inconsistency in Caesar's portrayal of the Germans. Elsewhere in the Gallic War, especially in Book 1, they are clearly nomadic. Book 6 , too, contains references to frequent movement. Gall. 6.23.1-2, however, depicts them as static and hostile. 
Romans can conquer if Caesar is in charge of the campaign, but not land that is naturally suited to becoming Roman. Caesar, on the other hand, offers a more complex approach to the landscape of Gaul. While there are some hostile spaces, the most common impression is of an orderly landscape that is ready for the Romans, but is inhabited by people who try to work against nature in their efforts to resist conquest. Although Cicero and Caesar are describing the same territory and the conflict, one author looks at Gaul with a view to turning it into fully Roman space, but the other one does not.

When Nye's concept of the anti-landscape is applied to these two authors, broader implications for how we read rhetorical descriptions of foreign spaces emerge. Anti-landscapes are hostile to human life, can spread, and can be transformed back into regular landscapes. The anti-landscapes in the two texts that I have discussed do not exclude all human life, but only the Romans. Whether we are dealing with a landscape or an anti-landscape is therefore a matter of perspective - a forest may be an anti-landscape for a Roman, but not for a German. The threat of an anti-landscape spreading presents a real concern, especially for Cicero. Most importantly, however, neither Cicero nor Caesar engage with the idea that anti-landscapes are transformable. Instead, they both offer a vision of land that is either already behaving like Roman territory or has to be destroyed through conquest. There is little possibility for rehabilitating anti-landscapes, and the gradual processes of transformation that make spaces Roman are not of interest to the authors. A landscape is either Roman by nature or it is not. 